Volume 5, Issue 1 (2016) 79-98 | Published online, 27 February 2017

The publication of the JEOD is supported by the Autonomous Province of Trento, Italy

\section{AUTHOR}

KIRI LANGMEAD

School of Geography, University of Nottingham

kiri.langmead@nottingham.ac.uk

\title{
Challenging the Degeneration Thesis: the Role of Democracy in Worker Cooperatives?
}

\section{ABSTRACT}

This paper uses data collected through written narratives, focus groups and participant observation in three small UK worker cooperatives to investigate the role of democracy in maintaining cooperatives' dual social-economic characteristic and resisting degeneration. More specifically, it adds to limited empirical literature countering the degeneration thesis by arguing that ongoing processes of individual-collective alignment, understood as central to the practice of democracy, help cooperatives to: balance varying and conflicting needs and aims; challenge the assumption underpinning the degeneration thesis; and transform degenerative "risks" into creative and productive spaces where new meanings and practices can be formed.

\section{KEY-WORDS}

WORKER COOPERATIVE, DEGENERATION THESIS, DEMOCRACY, ALTERNATIVE ECONOMY, SOCIAL-ECONOMIC CHARACTERISTIC, DUAL CHARACTERISTIC, WORKPLACE DEMOCRACY, COOPERATIVE.

JEL Classification: J54; P13 | DOI: http://dx.doi.org/10.5947/jeod.2016.005

\section{Acknowledgments}

I would like to thank my supervisors and all research participants for supporting me on my research journey. I thank also the editors and anonymous reviewers for their invaluable comments on earlier versions of this manuscript. In the spirit of this paper and journal, I would welcome comments on the article. 


\section{Introduction}

This paper uses data collected through written narratives, focus groups and participant observation in three small UK worker cooperatives to investigate the role of democracy in maintaining cooperatives' dual social-economic characteristic and resisting degeneration. More specifically it argues that ongoing processes of individual-collective alignment, understood as central to the practice of democracy, help cooperatives to balance varying and at times conflicting needs and aims, and challenge the assumptions underpinning the degeneration thesis.

While understood as central to cooperatives' identity and mission their dual characteristic, which conceives social and economic goals as interdependent, leads to an ongoing challenge to balance these often dilemmatic goals, and associated actions and practices (Somerville, 2007; Novkovic, 2012; Puusa, Monkkonen and Varis, 2013). This poses risks of degeneration (Cornforth, 1995; see also Diamantopoulos, 2012; Chen, Lune and Queen, 2013; Doherty, Haugh and Lyon, 2014) that are heightened by an economic context which promotes managerialism and "market-based solutions to social problems" (Eikenberry, 2009: 585). The degeneration thesis claims that worker cooperatives will inevitably succumb to external forces and the impact of internal characteristics (such as the development of informal hierarchies based on personality traits or length of member involvement) "to adopt the same organisational forms and priorities as capitalist business in order to survive" (Cornforth, 1995: 1). This claim is born from the perceived primacy and extension of the free market and private enterprise into all areas of social life; the promotion of competition and hierarchical, bureaucratic forms as a means to success and efficiency; and the assumption that individual interests will prevail over those of the collective (Burkett, 2011). Literature on the degeneration thesis draws clear connections between degeneration and organisational form (Somerville, 2007; Ng and Ng, 2009). Expanding on this connection Chen, Lune and Queen (2013) explain that organisational forms carry with them certain values. In doing so the authors recognize that cooperatives' democratic form is both essential to resisting degeneration and a point of vulnerability. In line with this view, Heras-Saizarbitoria (2014) and Somerville (2007: 15) argue that the risk of degeneration is heightened by the separation of values, organisational form and daily practice, and by the "weak exercise of internal democracy".

Despite the proposed centrality of democracy in resisting degeneration, empirical studies into the day-to-day practice of democracy are limited. A systematic literature review carried out by Luhman (2007) revealed only 22 ethnographic or case-based studies. Furthermore, a study carried out by Luhman in 2006 and a more recent review conducted by Land and King (2014), highlighted a specific gap in studies describing and engaging with the messy realities of democratic organising. Here Land and King highlight that, while it is understood to "permeate the entire organisation" (Novkovic, 2012: 93), as demonstrated by Beeman et al. (2009), Ng and Ng (2009) and Kokkinidis (2015), discussions on cooperative governance have tended to be restricted to board competencies and practices with a specific focus on larger scale organisations. This focus is reflected in the principle of democratic member control that foregrounds active participation in decision-making through the election of representatives and a commitment to "one member one vote" (International Cooperative Alliance, undated). Chatterton and 
Pickerill (2010) and Chatterton (2010) have addressed this gap in their studies of social centres. Cornwell (2012), Land and King (2014), and Kokkinidis (2015) have also made valuable contributions, analysing democratic practice in a UK voluntary sector organisation, and US and Greek worker cooperatives. I add to these articles by exploring democracy as an interconnected praxis of values, organisational form and daily practice, focusing specifically on how this interconnection challenges degeneration. As such the paper contributes to limited literature exploring the interconnection between democracy and degeneration (Bakaikoa, Errasti and Begiristain, 2004; Vieta, 2012; Meira, 2014; Storey, Basterretxea and Salaman, 2014), adding perspectives from small UK worker cooperatives that empirically challenge the degeneration thesis.

Following a brief review of processes of degeneration, and an introduction to the three case study organisations and research methods, the findings are presented in three sections. In section 4.1, the concept of democracy is explored to reveal the interconnection between values of equality, interdependence and autonomy; a fluid and opened organisational structure; and day-to-day practices of decision-making. Running throughout this praxis of democracy are ongoing processes of individual-collective alignment that see individuals and the organisation change and develop in response to one another. Focusing on changes arising from intergenerational encounters as one example of individual-collective alignment, section 4.2 argues that these processes bring to the fore convergences and divergences of values, organisational form and daily practice; create opportunities for divergences to be negotiated and addressed and, through this, transform degenerative "risks" into creative and productive spaces where new meanings and practices can be formed. Section 4.3 further explores processes of individual-collective alignment arguing that they enable members to draw on multiple and diverse experiences in the negotiation of contradictions and conflicting aims, values and needs. Combined, the sections contend that processes of alignment and the incorporation of diverse experience into decisions and practice challenge the pervasiveness of free markets and private enterprise into all areas of life, the necessity of hierarchical forms as a means to efficiency, and the assumed separation of individual and collective needs.

\section{Processes of degeneration}

Discussing the external sources of degeneration Chaves, Soler and Sajardo (2008) highlight the impact of institutional contexts and policies that promote "market-based solutions to social problems" (Eikenberry, 2009: 585). In this context, Sandoval (2016: 58) argues cooperatives appeal to both critics and moderate reformers of capitalism, with the latter understanding them to be supportive of "neoliberal discourses of entrepreneurship and individual responsibility". Expanding on these arguments, Borzaga, Depedri and Tortia (2009: 3) add that the policies referred to by Chaves, Soler and Sajardo (2008) assume the prevalence of self-interested and competitive behaviour, making individual and collective interests appear incompatible. Using data collected from interviews with worker-member-owners of Mondragon, Heras-Saizarbitoria (2014: 659) similarly argues that a rise in self-interest and increasing prominence of managerial discourse interconnect with the separation 
of cooperative principles and practice, resulting in a "rhetoric of abandonment of the cooperative spirit and an abstainer stance within the formal democratic organization". Such a loss of cooperative, solidaristic ethic is further perpetuated by demands for efficiency, productivity and rapid responses to market changes (Harnecker, 2012; Meira, 2014). Bringing these arguments together, we are minded of Chatterton and Pickerill's (2010: 487) warning that cooperatives may find themselves "cornered by modes of neoliberal governance, self-discipline and a creeping individualism" that simultaneously challenge their democratic form and their underlying social mission.

Beyond these external sources of degeneration, Cornforth (1995) highlights the risk of "constitutional degeneration". Capturing this risk, $\mathrm{Ng}$ and $\mathrm{Ng}$ (2009) highlight the challenge of eliminating positions of power and control arising from personal attributes. While such attributes are viewed as beneficial leadership qualities in hierarchical organisations they "are a more complex and nuanced issue in co-ops" ( $\mathrm{Ng}$ and $\mathrm{Ng}, 2009$ : 184), bringing with them the potential to increase or create gaps between "leaders" and "followers". The development of informal hierarchies may therefore limit capacities to resist, or create pathways for, degenerative tendencies (Kokkinidis, 2015). Similarly focusing on the potential impact of members, Somerville (2007) highlights the risk of degeneration arising from employing people based on their understanding and experience of market-based economic relations and competition, with little regard for the alignment of personal and organisational values. Conversely, members who have prior experience of solidarity and democratic participation can help to increase collective democratic consciousness and thus reduce risks of degeneration (Harnecker, 2012).

References throughout this brief review to the assumed prevalence of self-interested and competitive behaviour, challenges posed to the cooperative solidaristic ethic, and the risk of informal hierarchies, support understandings of democracy as a source of resistance and point of vulnerability to degeneration. Capitalism, through the adoption of hierarchy and managerialism, prioritises profit, market efficiency and individual ownership over values of egalitarianism. From this understanding of values as expressed through both the ways organisations are run (means) and the outcomes they produce (ends), it follows that when exposed to the pressure to adopt nondemocratic organisational forms, cooperatives will face deep challenges to the values and practices that shape their mission and actions. This heightened risk resonates with Parker et al.'s (2014: 35) discussion on means-end interdependence that concludes "we can't simply disentangle the question of how something is done from the broader issue of why it is done". Parker et al. (2014) argue that by ignoring mean-ends interrelations and the values embedded in and expressed through organisational form we risk supporting the inevitability of hierarchical economic relations and restricting opportunities to challenge "political assumptions that are solidified in organisational configurations" (Parker et al., 2014: 634).

The centrality of democracy to degenerative resistance is further supported by the four approaches to regeneration, identified by Cornforth (1995). Cornforth (1995) highlights the importance of: maintaining values and culture through ongoing connections to social movements; reproducing active membership through "careful selection and socialization" (id.: 30); reproducing values and 
democratic structure through everyday action; and maintaining an openness to opposition, criticism and difference supported through meaningful participation. Analysis of democratic praxis presented in this article reflects the latter three claims, highlighting their role in balancing social and economic needs and challenging the assumptions underpinning the degeneration thesis.

\section{Case studies and methods}

This paper uses data from two research projects. The first (RP1) was carried out in 2012 and three worker-members, one from each of the three following cooperatively run organisations: Vegetal, Collective Traders and Wholesome Coop ${ }^{1}$. The second (RP2) built on this scoping study, extending involvement with two of these three organisations (Vegetal and Collective Traders) to include multiple cooperative members over a longer time-scale (October 2014-June 2016). The three organisations involved in the research, while adopting different legal forms, are all trading enterprises owned and run, predominantly or solely, by their workers.

Vegetal is a small community shop established in 1986 to promote and raise awareness of the benefits of whole, and organically and locally grown foods. It has seven full-time members, one part-time bookkeeper and between six and eight part-time staff. All seven members and the parttime bookkeeper participated in RP2.

Collective Traders was set up in 2010 with the mission to "give people the choice and opportunity to live, work and play co-operatively and create a mutual local economy" (Peter, founder member). Central to this mission is the creation of meaningful work and the relief of unemployment, achieved through the development of projects centred on core areas of events, food, low carbon economies and social enterprise support. Projects, which comprise Collective Traders' main source of income, are carried out by a combination of employed and self-employed people, and volunteers.

Wholesome Coop is a vegetarian and vegan wholesaler. At the time of RP1, it had 10 worker members. According to the one member involved in the study, Wholesome Coop's aim is to promote both vegetarian and vegan food and cooperative working, and support other organisations involved in similar social struggles.

As captured by Steve (worker-member, Vegetal, RP2) in the following quote, all three of the organisations described experiencing and negotiating conflicting social and economic aims and needs. In the final line of this quote Steve expresses the interconnected nature of the organisations social and economic goals that constitutes the cooperatives' dual characteristic.

"It's an interesting balance to strike I think when you are looking at an organisation like this. To have that [business] focus without being overwhelmed by the need to make a profit. You know, that is important but it is not our primary goal. It is significant only in that it allows the business to continue to make that bit of profit that we make".

Pseudonyms have been used for both case study organisations and their members. 
In both studies participants were invited to share a written narrative outlining how they became involved in their cooperative. Fifteen of the 17 participants responded. Participants were invited to share their narratives at the start of focus groups run in both RP1 and RP2. A total of four focus groups (one during RP1 and 3 during RP2) lasting an average of two hours were carried out. In addition to written narratives and focus groups, RP2 included an 18-month period of participant observation. Observation enabled a more in-depth understanding of practices of democracy and the ways in which these supported the cooperatives' dual characteristic and resistance to the risk of degeneration (for further discussion see Langmead, forthcoming). A summary of the methods used can be found in Table 1 .

Table 1. Methods summary

\begin{tabular}{|c|c|c|c|c|c|}
\hline Member & $\begin{array}{l}\text { Relationship } \\
\text { to organisation }\end{array}$ & Organisation & Observation & Written narrative & $\begin{array}{c}\text { Focus group } \\
\text { [location] }\end{array}$ \\
\hline Adam & Worker-member & Vegetal & -- & Typed & \multirow{3}{*}{$\begin{array}{l}\text { FG1 }(08 / 05 / 12) \\
\text { [Adam's house] }\end{array}$} \\
\hline Dave & Worker-member & Collective Traders & - & Typed & \\
\hline Roy & Worker-member & Wholesome Coop & -- & Typed & \\
\hline Ewan & Worker-member & \multirow{8}{*}{ Vegetal } & \multirow{8}{*}{$\begin{array}{l}\text { Nov 2014- } \\
\text { April } 2016\end{array}$} & E-mailed & \\
\hline Isla & Worker-member & & & Hand written & $\begin{array}{c}\text { FG2 (19/05/15) } \\
\text { [Vegetal office] }\end{array}$ \\
\hline Richard & Worker-member & & & Typed & \multirow{4}{*}{$\begin{array}{l}\text { FG3 }(26 / 05 / 15 \\
\text { [Vegetal office] }\end{array}$} \\
\hline Steve & Worker-member & & & E-mailed & \\
\hline Lucy & Worker-member & & & Typed & \\
\hline Matthew & Part-time bookkeeper & & & -- & \\
\hline George & Worker-member & & & E-mailed & - \\
\hline Andy & Worker-member & & & -- & -- \\
\hline Kelly & Worker-member & \multirow{6}{*}{ Collective Traders } & & Typed & \multirow{6}{*}{$\begin{array}{c}\text { FG4 }(09 / 06 / 15) \\
\text { [Collective } \\
\text { Traders office] }\end{array}$} \\
\hline Rebecca & Worker-member & & & Typed & \\
\hline Helen & Worker-member & & & Typed & \\
\hline Sara & Worker-member & & May 2016 & Typed & \\
\hline Rob & Worker-member & & & Typed & \\
\hline Peter & $\begin{array}{l}\text { Founder member and } \\
\text { active worker-member }\end{array}$ & & & Typed & \\
\hline
\end{tabular}

Focus groups were transcribed and analysed alongside written narratives. Observed meetings and conversations were recorded and transcribed where possible. Where this was not possible, jot notes were taken during my time in the field and written into a field diary immediately after. Analysis of this data involved a process of eye-balling, highlighting and line-by-line in vivo coding that drew me into the data and prevented "theoretical flights of fancy" (Ryan and Bernard, 2003: 91). This 
was followed by the rationalization of codes, which helped to create a path from original in vivo codes to a more abstract level of analysis, and a process of cut and sort that enabled me to identify similarities, differences and contradictions, and to "move beyond individual cases and to define patterns" (Charmaz, 2004: 512).

The next three sections focus on key themes arising from the analysis of focus groups, observations and transcribed meetings and conversations. In section 4.1, I explore what constitutes democracy in the three participating organisations, reflecting on issues of organisational structure, shared values and daily practices, and their interconnection. Sections 4.2 and 4.3 focus on processes of individual-collective alignment and the spaces these processes create for diversity to be utilised and contradictions to be negotiated. My aim throughout is to empirically explore how democracy helps cooperative to resist risks of degeneration and maintain their dual characteristic.

\section{4. Findings}

\subsection{Understandings of democracy}

For Eikenberry (2009: 583) democracy, when focused on collective problem solving rather than individual self-interest, can offer a counterdiscourse to neoliberal capitalism and "one possible way to resist colonisation by the markets". Kokkinidis (2012: 244) similarly found through research with Greek worker cooperatives that an "emphasis on horizontality and participatory democracy" played a key role in resisting tendencies towards hierarchy. From this perspective democracy is understood, not simply as a process of decision-making or organisational structure, but as a means though which to "challenge conventional working practices and associated values" and "reject dominant market discourse" (Eikenberry, 2009: 583). This view supports Somerville's (2007: 15) claim that democracy, when practiced to connect values, organisational form and daily action, can play an important role in resisting degeneration, not least by challenging the assumptions underlying the degeneration thesis. Before exploring this claim in more detail I will draw on data collected through RP1 and RP2 to outline what constitutes democracy in the case study cooperatives.

The research discussed in this article found, like Kokkinidis (2015) and Beeman et al. (2009) that democracy cannot be captured by participation in formal structures alone. The governing documents that outline agreed practices of member engagement, including processes of electing representatives and organising general meetings, were viewed as a "legal vehicle" and "loose framework for action" (Peter, Collective Traders). The practices and objectives expressed in these documents were kept purposefully open, allowing room for the organisations to shift and redefine themselves over time. Thus, while they were respected and, on the most part adhered to, formal structures were seen as fluid and negotiable by both current and future members. Most notably, Andy (Vegetal) commented that, despite Vegetal's clear aim to promote vegetarian and organic food, he would not want to include "vegetarian" in the organisations objectives in case a future 
member felt that it was appropriate to sell ethically sourced meat. Andy's comment brings to the fore members' understanding of democracy as an act of being open to present and future others as communicative beings (Gibson-Graham and Roelvink, 2010: 324; see also Webb and Cheney, 2014). This understanding resonates with Byrne and Healy's (2006: 250; emphasis added) claim that "The challenge is not in constructing [the] subject in relation to a particular symbolic order (the law governing coops), but in keeping the space of decision open, keeping the negativity of communal production intact at every phase $[. .$.$] of collective economic activity". Thus, while I was$ initially concerned that members' loose understanding of the purpose and meaning of governing documents would increase risks of degeneration, over the course of RP2 I found this openness to be, not counter to, but essential for practices of democracy. As I will explore in the next section, it created space for ongoing processes of individual-collective alignment through which members were able to meaningfully shape and inform the organisations' direction.

Democracy was understood therefore as a relational process that creates opportunities for members to inform action and "take initiatives on daily matters" (Kokkinidis, 2015: 863) within a framework of principles and objectives decided by the (current) collective. While varying over time, a number of core principles remained constant. First, members in all three organisations expressed a commitment to equality. As Dave (Collective Traders) explained in RP1, "if you join a co-op and are into co-op working you are saying that you are into equality". Here, Dave frames equality as a "deep part of members' personal identity" (Snyder and Briggs, 2003: 7). Supporting this deep embedding Adam (Vegetal) added: "Equality is another one of those things I tend to take for granted, I forget about it. There is a comfiness about it".

The "comfiness" referred to here developed gradually as members' aspirations for equality were realised through practices of "equal say and equal pay" (Roy, Wholesome Coop) that challenged the necessity and inevitability of hierarchy. Delving deeper into member's commitment to equality I found it to be underpinned by a rejection of fixed notions of identity and "good and bad tactics" (Chatterton and Pickerill, 2010: 482) that exclude, persuade and coerce, and concomitant foregrounding of "questions, difference and newness" (id., 2010: 482). Thus as Takacs (2003) and Emejulu (2011) explain, I found the acceptance and practice of equality to enable the organisations to utilise advantages arising from the bringing together of diverse individuals.

Second, and interrelatedly, I found a shared desire, amongst members of all three organisations, to take control of their own working lives. This is captured in the following quote taken from FG3. The ensuing discussion connects members' desire for control to the concept of autonomy.

"Everybody talked about control in one way or another, taking control of one's situation, and for me that's like, having studied and taught entrepreneurialism for a number of years, there is the whole area relating to that about the 'locus of control'. It's about the responsibility to kind of like [Sara: Affect] accept or take control of one's own situation. And, you know, the ability to do that is quite important" (Peter, Collective Traders). 
Pondering this point, Rob (Collective Traders) explained:

"I think this leads into my point, which is linked to autonomy. Like the power to hold to account is key. It's the ability to hold to account that is essential about the coop but it doesn't need to be that every decision is micro discussed. So you have to have autonomy within the framework of something that like ultimately gives you an equal say and an equal voice".

At first glance the desire to "[take] control and responsibility of one's own life", especially when connected to the study of entrepreneurialism, speaks to the individualised project of selfrule: a project that utilises the concept of autonomy as a vehicle to responsibilisation (Böhm, Dinerstein and Spicer, 2010). As such, the drive to autonomy is a potential source of degeneration. However, when positioned within a framework of equality and in relation to Rob's understanding of accountability - the ability to "hold each other accountable to [a] sense of joint enterprise" (Wenger, 2000: 229, original emphasis) —autonomy is reframed as a "collective project" that shapes our connection to others and supports shared responsibility. From this perspective, the subject becomes most present in a collectively constructed "social, political and moral space" that "produces individual and collective experiences" (Beeman et al., 2009: 869). Thus, as Dave (Collective Traders) explained in RP1, his organisation's democratic practice is not restrictive as he first predicted, but contrarily provides "a good framework that allows creativity". As I will explore in the next section, this creativity is supported by the continuous alignment, dis-alignment and re-alignment of individual and collective aims, experiences and needs through which members develop a "collective consciousness" and sense of interdependence. This collective consciousness constitutes "awareness of the interests and problems of [...] co-workers; a willingness to contribute resources towards their solution; and the materialization of this disposition into statements and/or actions" (Harnecker, 2012: 107-8). The connection of values of equality, interdependence and autonomy, organisational form, and daily practice is thus demonstrated in the development of working patterns and practices that both meet the needs of the organisation and enable members to utilise their knowledge, skills and experience when making day-to-day decisions, from what to buy from the wholesale market and how to organise a delivery round to the development of long-term objectives and meeting structures.

My argument here is twofold. First, shared values of equality, interdependence and autonomy, an open and fluid organisational form, and daily practice, that interconnect to constitute democracy, challenge individualised notions of the self and foster a solidaristic ethic (Chatterton and Pickerill, 2010). As such they dissolve the incompatibility between individual and collective needs and the assumption that individual interest will always prevail over those of the collective. Second, processes of individual-collective alignment, enabled by and running throughout this practice of democracy, support the enactment of values and member creativity through which diverse skills knowledge and experience are brought together to balance varying (and at times contradictory) needs and aims. 
Before exploring this claim in more detail it is import to recognise that the democracy described here does not eliminate risks of exclusion or the development of informal hierarchies. Focusing on the former in RP1, Roy (Wholesome Coop) recognised:

"You are constrained a certain amount by the preconceptions that you have got from the outside world.

Women still get talked over in co-ops".

Participants expressed a specific concern that the majority of workers and customers in their organisations are white and middle-class. Participants debated why it might be, identifying the pressure associated with on-going debate and decision-making, and the abstraction of liberal cooperative ideals as possible causes. Reflecting on findings from RP2, I would add to this the necessity to work for relatively low wages and to contribute voluntary time. Such practices were particularly prevalent in Collective Traders where income was not always high enough to cover costs, especially in the early days of project development. While members of Vegetal were no longer required to volunteer, they did experience dramatic cuts in wages during lean times, sharing the burden of reduced income rather than forcing redundancies. In both cases, members' willingness to accept financial hardship was driven by passion, values and the knowledge that their "voice is being heard [and that] we are all going in the same direction" (Lucy, Vegetal). Thus, like Kay (2006), participants recognise that building relationships based on shared values can be an exclusionary process. This was further supported in RP2 where participants identified challenges associated with members not fitting in or aligning with the organisations' needs and practices: a challenge that in some cases resulted in conflict and member departure. While not denying these challenges and their negative impact on both individuals and the collective, the fact that they are recognised, critically explored and negotiated is reflective of the organisations' practice of democracy and crucial to limiting risks of degeneration.

\subsection{Processes of individual-collective alignment}

Research participants in RP1 described their cooperatives as bringing together unique individuals in practice. They explained:

Adam (Vegetal): "It is invasive from outside a group that they think everyone thinks the same, and you think there is no way that everyone will have the same focus"

Dave (Collective Traders): "I think it depends on the coop and what people join it for. You expect everyone to be in the same area. We have some quite animated discussions at Collective Traders about what we should and shouldn't do, but we are all, that horrible saying, 'on the same page'. So it is a discussion within parameters I think"

Roy (Wholesome Coop): "Yes, but there is a massive scope within that sphere [Dave: yes totally]. There is a general agreement to not liking certain things but people have different focuses". 
Reflecting on my observations of, and personal involvement in, Vegetal and Collective Traders this exchange captures participants' experience of distinct motives, beliefs and aims, "different approaches and interests", "different skills" and "accumulated experience and expertise" (Adam, Vegetal) being brought together, respected and valued for their collective benefit. In Checkoway's (2009: 10) terms, "difference" and "unity" are combined in the same effort. Such diversity in thinking and focus is, of course, not unusual in organisations. Rather, I argue in this section that what is distinct is the ways in which this diversity is utilised and negotiated to concomitantly shape both individual and collective ways of knowing and doing. As indicated in Dave's comment above, this continuous negotiation, and associated organisational fluidity, creates space for "animated discussions" that support democratic member control and the balancing of the cooperatives' dual identity. Longer term involvement and reflection carried out in RP2 reinforced my understanding of the process and role of individual-collective alignment, specifically by revealing how Collective Traders and Vegetal have developed in response to changes in membership over time.

Since my departure as a member and worker from each organisation in 2013 and re-entry as a participant researcher in 2014, both Vegetal and Collective Traders experienced dramatic changes to their membership. Vegetal saw four long-term members leave the organisation, and three new members and one part-time, non-member bookkeeper join. Collective Traders witnessed the departure of two of the three founder members and two long-term members, again, accompanied by the recruitment of four new members. Space does not allow for discussion around the multiple causes of these member departures. The focus here is on the formative impact of new members, specifically their use of skills, interests and experiences to challenge existing practices and competencies and bring about organisational change. Of note, in response to new members' skills, passions and aspirations, Collective Traders experienced a refocusing of organisational activity towards events, food, enterprise support and low carbon living, and an increased prioritisation of member involvement in strategic and financial decision-making. In Vegetal, organisational changes have taken the form of improved financial transparency, shifts in practices of role sharing and the development of a clearer marketing and business plan. The following observations and exchanges, taken from my RP2 fieldwork diary and one focus group transcript, illustrate the development of the latter and its connection to the arrival of new members, Richard and Lucy.

In my fieldwork diary I wrote: "On my way down stairs from the office I spotted a typed up 'business plan'stuck on the wall. I asked Steve, who was pricing wholefoods in the adjacent stockroom, when it was produced.

Steve (from fieldnotes): "Richard did it after the last coop meeting. It's a bit different. I do find that I start to drift a bit over time, and it's a bit bossy but it might help to keep us on track. Have you seen the chart on the back of the door in the office?"

Me: "No."

Steve (from fieldnotes): "In the office on the way to the toilet there is a chart with a list of tasks on it and initials next to them. Just to remind us what the main jobs are". 
The business plan and task chart referred to by Steve clearly identified formerly implicit goals and objectives, and allocated time-bound tasks such as ordering, contract renewal, and building maintenance, previously performed on an ad hoc basis, to specific members. Steve's tone and expression acknowledged that this new approach did not align with how Vegetal is used to operating but may help to address recurrent issues, particularly those relating to "drifting off track", tasks being left incomplete, and the consequent inefficient use of time and money. Over the course of my research I witness increasing acceptance of this "more business-like" approach. In FG2, five months after his initial reactions, Steve (Vegetal) explained:

"And certainly we were interested in both Richard and Lucy for the skills that they demonstrated in their previous [jobs], of the things that they were bringing from a different environment really. And I think that both of them have made a significant difference to the way that the company feels and the sort of businesslike approach that we have got to things. The more business-like approach anyway than we have had in the past. [...] But having that sort of, like I say, I think it has been interesting having that new input into the company. And Matthew too, in the same way, you are bringing a sort or clarity to the process of putting numbers into a machine, which you know, it sounds fairly simple probably to you, but for us that's a bit radical actually! To know and to have access through you to it which is what was missing".

Steve acknowledges in this quote the impact that new members, with new ideas, skills and perspectives, have had on the organisation. In this case Richard and Lucy drew on their experience of working in a large corporate organisation and small family business, and Matthew on his experiences of living and bookkeeping in a housing cooperative, to question existing practices and introduce new approaches to organising. While the introduction of the business plan and increased clarity of financial accounting could have been conceived as a means to degeneration through managerialism and a drive to efficiency, the negotiation and development of these practices through process of individual-collective alignment contrarily resulted in new systems that supported transparency, participation and the maintenance of Vegetal's dual characteristics. It did so, not least, by opening debates about the necessity of, and extent to which, certain values, aims and practices, including established practices of role sharing and collective decision-making, should be balanced against the need for efficiency and financial growth. Crucially, the opening of deliberative spaces was supported by a shared commitment to cooperative and non-hierarchical ways of working that, as I observed in the case of Richard and Lucy, develop gradually over time.

I observed similar processes of concomitant individual-collective change arising in Collective Traders. This can be seen in the following meeting extract. The exchange followed a revelation from Peter, the one remaining founder member, that Collective Traders had purchased equipment to build a new stage.

Peter: "It would be nice, if you know, we kind of anticipated those sorts of decisions, like a month ahead, here's what we are planning to do [Helen: Yes], how does everyone feel about that? [Then spend] a few minutes to kick it around".

Sara: "You know you [Peter] were saying about not wanting to feel like the founder member or like this hierarchical kind of thing, I think the fact that you are the only one knowing what those sorts of spends are month to month". 
Helen: "And also, what's in the bank".

Sara: "Yes, and you are the only one with that worry".

Helen: "I have no idea what the bank account looks like [laughs]".

[...]

Peter: "Yes great, ask these questions and we will create a space to ask, because that's the only way that it is going to happen".

[...]

Helen: "I'm not criticising, I'm just saying it's very difficult to be part of a decision about whether we can make a purchase or not if you have no concept of what the bank balance. [Rob: Your financial situation, yes]".

Peter: "That's the difference, just to be really brutal about it, that's the difference between being a supplier of a service and an active member of a co-op".

We see in this quote, new members Rob, Helen and Sara challenging existing systems and informal hierarchies that limit member participation. Peter's closing comment indicates that these challenges have come alongside a necessary shift in member subjectivity from a self-employment/ employer mentality to a cooperative ethos, most notably new member's acceptance of their active role in implementing desired change and willingness to experiment with modes of democratic organising. Since this meeting Collective Traders has established regular monthly meetings and an online accounting system that have improved financial transparency and member participation.

In both of the cases described the adoption of cooperative and democratic subjectivities occurred gradually, alongside and enabled by, an emergent organisational focus and form (see also Cornwell, 2012; Vieta, 2012). New members were not, in other words, simply inducted into an "objective structure [already] imbued with meaning" (Benford and Hunt, 1994: 491). Rather they became part of the organisation through acts of collaboration and the interaction of difference; processes of shared learning; and the development of new ways of knowing, thinking and being together (Wenger, McDermott and Snyder, 2002). I contend that through these processes and encounters degenerative "risks", such as the drive for efficiency, are transformed into creative and productive spaces where new meanings and practices can be formed (Chatterton and Pickerill, 2010). These productive spaces constitute 'constructive disputing' (Childs, 2003) and shared learning that draw together varying and even competing perspectives to inform and redefine competencies and enterprise. The drawing together of multiple perspectives and experiences is the focus of the next section.

\subsection{Utilising multiplicity and contradiction}

Through processes of individual-collective alignment described, members became more aware of their contradictions and the "complex narrative[s] of the self", which contextually and temporally combine varying identities, practices, aims and needs (Chatterton and Pickerill, 2010: 487). Again, this awareness arose at points of encounter at which individual subjectivities are varyingly reinforced, 
reinterpreted and redefined in light of new experiences and knowledge (Benford and Hunt, 1994). The following quote is taken from a focus group with Collective Traders. I had asked participants to share stories, written prior to the focus group, about how they came to work at Collective Traders. Sara shared her story after Peter and Helen.

"I realised I probably hadn't put some of the stuff that was really poignant and it was hearing your stories that made me realise what I hadn't put in here, which was that before I started working for the Academy [a corporate owned music venue], which was my job previous to Collective Traders, I was working for Rototom. Rototom is Europe's biggest Reggae festival, and their motto is 'another world is possible' and it was totally about community. The whole sort of atmosphere of the festival was about kind of education and change, environmentally minded - everything was zero carbon footprint. And it had been in the Alps for 16 years and it was so inspiring. And then I finished my Uni degree, got the job at the Academy and it was like the polar opposite of what I had just been doing, like literally the polar opposite. And it was just like 'no, [don't think about community or environment, just] make money, make money'. And I thought 'if I do a good job here I will be able to make little changes [locally] and eventually once you have proven to them you are making money, surely then you can have some positive influence.' And then after 4 years I realised that was flogging a dead horse so, that was very much what inspired me to come to Collective Traders and talk to Peter about alternative kind of ways of working."

We see in this quote that Sara was made aware of the relevance of her experience of Rototom though her encounter with other members. Contrasting this experience to her time working in a hierarchical, corporate organisation, Sara's story demonstrates how the multiple narrative of the self can enter into and shape the form and focus of the cooperative. Members experiences of community organising and consequent shared "do it yourself mentality", combined with experiences of redundancy, unemployment and disempowerment in hierarchical organisations, led them to conceive Collective Traders as "a centre for social action" where people are empowered to "take more action on the things that they are passionate about" (Helen, Collective Traders). Moreover, these experiences were used to demonstrate that "the market" does not extend into all areas of social life, that hierarchy is not essential to success, and that individual interests do not always prevail over those of the collective. Thinking again to processes of individual-collective alignment, individual experiences were, in other words, given new and coherent meaning as participants "orient[ed] their lives to that of their milieu" (Beeman et al., 2009: 880). In the cases discussed here, these new meanings were used to challenge assumptions underpinning the degeneration thesis.

In his written narrative George (Vegetal), like Sara, expressed discomfort at the contradictions between personal values and actions, often internalised in work. Reflecting on his own discomfort at doing work for large oil companies, he explained:

"I find it a bit odd that people who work for a big company can be really nice and middle class and go to church and so on, but what the company is doing collectively is actually quite destructive. An odd paradox."

We see in the following exchange (taken from a meeting at Vegetal) that the open space of democracy, created by acceptance of processes of individual-collective alignment, does not eliminate these contradictions but does create opportunities for them to be identified and negotiated. 
Engagement in deliberation created moments of reconnection, counter to experiences of abstraction that separate our individual and collective selves from our conscious doing and values (Cornwell, 2012). During a discussion on their choice of energy supplier, members brought together financial concerns relating to business sustainability with ethical concerns, which as George suggested above, are often confined to spaces outside of work.

Andy: "I will just put in ethical energy suppliers into Google and see what comes up".

Richard: "At the end of the day we have to keep the business afloat".

Andy: "But then if you move away from that you are not...?"

Matthew:" Some of the ethical ones have not so obviously tangible benefits as well. Like I use Good Energy at home..."

Andy: "Yes, that's it, we use Good Energy".

Matthew: "A lot of people who work here use these ethical things but then through the business that is your business collectively you are using these horrible corporates that build nuclear power stations and destroy the planet."

This, and similar negotiations observed at Collective Traders, capture the dual socialeconomic characteristic of cooperatives. On the one hand members recognised the need to "compete with supermarkets" (Lucy, Vegetal), keep costs down and cover their expenses. On the other, they acknowledged their roles as cooperatives and socially responsible employers. While these contradictions, specifically demands for efficiency and meeting financial needs, created risks of degeneration collective and individual openness to challenge and ongoing processes of alignment created opportunities for members to draw on diverse experiences and logics to engage in "ethical economic decision-making" (Cameron, 2009: 92). This is illustrated in the RP1 focus group where Roy (Wholesome Coop), Adam (Vegetal) and Dave (Collective Traders) explained:

Roy: "We have regular meetings, and you haven't got the person in charge. There are people that can speak louder and for longer and sometimes get listened to more, but there is that notion that everyone has an equal say, and when someone who doesn't speak as much speaks, we kind of encourage it and listen to it." Adam: "You make decisions in a meeting like that, you can pull it all over the place, you can give ethical considerations as much importance in that meeting as the need to make money, the need to have a profit at the end of the year, so the decision can be made, there isn't the individual feeling responsible for profit controlling the meeting, so you can deviate from that."

Dave: "I think that that makes coops more resilient in a way."

Adding to Dave's claim that deliberation makes cooperative more resilient, Adam later explained:

Adam: "Yes, I think if you are a sole trader, you are very vulnerable to switches of direction [Dave: yes]. When you are on your own, you are a bit vulnerable to be being washed around with the stress, whereas having all of those people around you that are different but perhaps similar, have similar ideals, keeps you a bit more steady." 
As Adam, Roy and Dave indicate here, I observed in RP2 that celebrating and utilising difference through ongoing processes of individual-collective alignment contributed to the uniqueness and resilience of each organisation, in particular helping them to collectively and continuously reassess their values and aims and find a balance between these and sometimes conflicting economic needs. This process allowed time and space for both members and the organisation to "shift its stance, to meld a little more with its surroundings" (Gibson-Graham and Roelvink, 2010: 322); to incorporate new ways of knowing and being; and continuously reinvent competencies and enterprise that reflect the multiple and changing needs and aspirations of members. Through this, assumptions underpinning the degeneration thesis were challenged and the cooperatives unique dual characteristic maintained (Varman and Chakraberti, 2004). In Wenger's (1998: 96) words, the democratic praxis described in this paper created organisations that are at once "highly perturbable and highly resilient".

\section{Conclusion}

How practices of democracy help cooperatives to resist risks of degeneration and maintain their dual characteristic has received inadequate empirical attention, specifically in the case of small worker cooperatives. This paper responds to this gap. Drawing on data from written narratives, focus groups and participant observation with three UK cooperatives the paper makes contributions to our understanding of the role of democracy in maintaining cooperatives' dual characteristic and resisting degeneration. Recognising, as Ed Mayo (Secretary General of Co-operatives UK, 2016) aptly expressed, "when you have seen one co-op, you have seen one co-op", my aim here is not to map a generalizable reality but rather to present "fragments of discourse" (Foley, 2010: 476) that offer an insight into the social process constituting democracy and resistance to degeneration. Acknowledging the limits of generalizability I hope that this article will spark conversations and further investigation into the purpose and practice of democracy in small worker cooperatives. Specifically I would call for further research into the challenging processes of negotiating conflicting aims and needs in the UK context. Understanding the connection between these processes and organisational form has potential benefits for cooperatives and the wider social enterprise and charitable sector struggling with a dual characteristic and the risk of degeneration.

The three cooperatives involved in this study conceived democracy as a relational process, irreducible to participation in formal structures or practices. This was expressed most clearly in the members' approach to framing formal documents, including their understanding of written objectives and processes of member engagement, as "loose frameworks for action" (Peter, Collective Traders) always open to change and challenge. Combined with shared values of equality, memberorganisation interdependence, and autonomy, expressed in practices that embraced the creative potential of diversity, this fluidity opened space for ongoing processes of individual-collective 
alignment through which both members and their organisations developed and changed.

These processes of alignment are seen most prominently in the gradual formation of cooperative and democratic subjectivities and the development of new organisational practices. It was through these processes of individual-collective alignment that convergences and divergences of values, actions and norms became most apparent. They created, in other words, space for values, organisational form and daily practice to be questioned and re-aligned through the development of new approaches and ways of being together. As such, risks of degeneration arising most prominently from pushes towards efficiency and managerialism, and the development of informal hierarchies, were transformed into creative and productive moments that capitalised on member diversity, constructive disputing and engagement in shared learning.

Further exploration of processes of individual-collective alignment, focusing on the negotiation of multiple and at times conflicting aims and needs, reinforced the role of democracy in the generation of such creative moments. Research showed that members' experiences and aspirations, specifically those connected to values of equality, interdependence and autonomy, were reinforced, reinterpreted and given new meaning as they were realised through practice and interaction, and connected to the cooperatives' organisational form. Thus, as members developed cooperative and democratic subjectivities and engaged in processes of alignment, experiences and values previously positioned outside of the space of "work" were reframed as learning opportunities and welcomed into decision-making processes. This enabled decisions to be "pulled all over the place" (Adam, Vegetal), opening opportunities for "ethical economic decision-making" (Cameron, 2009: 92). Again, risks of degeneration associated with the cooperatives' dual characteristic were reframed as opportunities for experimentation through which organisations could combine multiple practices, values and experiences and respond to challenges in temporal, "strategic and holistic ways" (Burkett, 2011: 121). In these experimental spaces the incorporation of diverse experiences, including those of grassroots organising, family life, sport and music, play a crucial role in challenging the pervasiveness of free markets and private enterprise into all areas of life, the assumed necessity and suitability of hierarchical organisational forms and the inevitable privileging of individual over collective needs. The very assumptions underpinning the degeneration thesis were, in other words, thrown into question. 


\section{References}

Bakaikoa, B., Errasti, A. \& Begiristain, A. (2004). Governance of the Mondragon Corporacion Cooperativa, Annals of Public and Cooperative Economics, 75(1): 61-87. DOI: https://doi.org/10.1111/j.1467-8292.2004.00243.x

Beeman, J., Guberman, N.,Lamoureux, J., Fournier, D. \& Gervais, L. (2009). Beyond structures to democracy as culture, American Behavioral Scientist, 52: 867-884. DOI: https://doi.org/10.1177/0002764208327663

Benford, R. \& Hunt, S. (1994). Identity talk in the peace and justice movement, Journal of Contemporary Ethnography, 22(4): 488-517. DOI: https://doi.org/10.1177/089124194022004004

Böhm, S., Dinerstein, A.C., \& Spicer, A. (2010). (Im)possibilities of autonomy: Social movements in and beyond capital, the state and development, Social Movement Studies, 9(1): 17-32. DOI: https://doi.org/10.1080/14742830903442485

Borzaga, C., Depedri, S. \& Tortia, E.C. (2009). The role of cooperative and social enterprises: a multifaceted approach for an economic pluralism, Euricse Working Papers,0/09. DOI: http://dx.doi.org/10.2139/ssrn.1622155

Burkett, I. (2011). Organizing in the new marketplace: Contradictions and opportunities for community development organizations in the ashes of neoliberalism, Community Development Journal, 46(supplement 2): 111-127. DOI: https://doi.org/10.1093/cdj/bsr002

Byrne, K. \& Healy, S. (2006). Cooperative subjects: Toward a post-fantasmatic enjoyment of the economy. Rethinking Marxism, 18(2):241-258. DOI: https://doi.org/10.1080/08935690600578919

Cameron, J. (2009). Experimenting with economic possibilities: ethical economic decision-making in two Australian community enterprises. In: A. Amin (Ed), The social economy: International perspectives on economic solidarity. London: Zed Books.

Charmaz, K. (2004). Grounded Theory. In: S. Hesse-Biber \& P. Leavy (Eds.), Approaches to qualitative research: a reader on theory and practice. Oxford: Oxford University Press, pp. 497-521.

Chatterton, P. (2010). So what does it mean to be anti-capitalist? Conversations with activists from urban social centres, Urban Studies, 47(6): 1205-1224. DOI: https://doi.org/10.1177/0042098009360222

Chatterton, P. \& Pickerill, J. (2010). Everyday activism and transitions towards post-capitalist world, Transactions of the Institute of British Geography, 35, pp.475-490. DOI: https://doi.org/10.1111/j.1475-5661.2010.00396.x

Chaves, R., Soler, F. \& Sajardo, A. (2008). Co-operative governance: The case of Spanish credit co-operatives, Journal of co-operative studies, 41(2): 30-37.

Checkoway, B. (2009). Community change for diverse democracy, Community Development Journal, 44(1): 5-21. DOI: https://doi.org/10.1093/cdj/bsm018

Chen, K., Lune, H. \& Queen, E.L. (2013). How values shape and are shaped by nonprofit and voluntary organizations: The current state of the field, Nonprofit and voluntary sector quarterly, 42(5): 856-885. DOI: https://doi. org/10.1177/0899764013480273

Childs, J.B. (2003). Trans-communality: from the politics of conversion to the ethics of respect. Philadelphia: Temple University Press.

Cornforth, C. (1995). Patterns of cooperative management: Beyond the degeneration thesis, Economic and Industrial Democracy, 16(4): 487-523. DOI: https://doi.org/10.1177/0143831X95164002

Cornwell, J. (2012). Worker Co-operatives and spaces of possibility: An investigation of subject space as collective copies, Antipode, 44(3): 725-744. DOI: https://doi.org/10.1111/j.1467-8330.2011.00939.x

Diamantopoulos, M. (2012). The developmental movement model: A contribution to the social movement approach to co-operative development, Journal of Co-operative Studies, 45(2): 42-56.

Doherty, B., Haugh, H. \& Lyon, F. (2014). Social enterprise as hybrid organisations: A review and research agenda, International Journal of Management Reviews, 16(4): 417-436. DOI: https://doi.org/10.1111/ijmr.12028

Eikenberry, A.M. (2009). Refusing the market: A democratic discourse for voluntary and nonprofit organizations, Nonprofit and voluntary sector quarterly, 38(4): 582-596. DOI: https://doi.org/10.1177/0899764009333686 
Emejulu, A. (2011). Re-theorizing feminist community development: towards a radical democratic citizenship. Community Development Journal, 46(3): 378-390. DOI: https://doi.org/10.1093/cdj/bsr032

Foley, D. (2010). Critical ethnography: the reflexive turn, International Journal of Qualitative Studies in Education, 15(4): 469-490. DOI: http://dx.doi.org/10.1080/09518390210145534

Gibson-Graham, J.K. \& Roelvink, G. (2010). An Economic Ethics for the Anthropocene, Antipode, 41(1): 320-346. DOI: https://doi.org/10.1111/j.1467-8330.2009.00728.x

Harnecker, C.P. (2012). Democracy and solidarity: A study of Venezuelan cooperatives. In: Atzeni, M. (Ed.), Alternative Work Organisations. Basingstoke; New York: Palgrave Macmillan, pp.103-128.

Heras-Saizarbitoria, I. (2014). The ties that bind? Exploring the basic principles of worker-owned organizations in practice, Organization, 21(5): 645-665. DOI: https://doi.org/10.1177/1350508414537623

International Cooperative Alliance (undated). Cooperative identity, values and principles. https://ica.coop/en/whats-coop/co-operative-identity-values-principles [Accessed: 29 October 2016].

Kay, A. (2006). Social capital, the social economy and community development, Community Development Journal, 41(2): 160-173. DOI: https://doi.org/10.1093/cdj/bsi045

Langmead, K. (forthcoming). From cooperative practice to research and back: learning from the emotional experience of ethnography with two social enterprises, Social Enterprise Journal.

Land, C. \& King, D. (2014). Organizing otherwise: Translating anarchism in a voluntary sector organization, Ephemera, 14(4): 923-950.

Luhman, J.T. (2006). Theoretical postulations on organization democracy, Journal of Management Inquiry, 15(2): 168185. DOI: https://doi.org/10.1177/1056492605275419

Luhman, J.T. (2007). Worker-ownership as an instrument for solidarity and social change? Ephemera, 7(3): 462-474.

Kokkinidis, G. (2012) In search of workplace democracy, International Journal of Sociology and Social Policy, 32(3/4): 233256. DOI: http://dx.doi.org/10.1108/01443331211214785

Kokkinidis, G. (2015). Spaces of possibilities: workers' self-management in Greece. Organization, 22(6), 847-871. DOI: https://doi.org/10.1177/1350508414521098

Mayo, E. (2016). Democracy at work: co-operation and civil society, Opening address at ESRC Seminar, 29 November 2016, University of Leicester.

Meira, F.B. (2014). Liminal organization: Organizational emergence within solidary economy in Brazil, Organization, 21(5): 713-729. DOI: https://doi.org/10.1177/1350508414537621

$\mathrm{Ng}$, C. \& Ng, E. (2009). Balancing the democracy dilemmas: Experiences of three women workers' cooperatives in Hong Kong, Economic and Industrial Democracy, 30(2): 182-206. DOI: https://doi.org/10.1177/0143831X09102419

Novkovic, S. (2012). The balancing act: Reconciling the economic and social goals of co-operatives. In Molina, M.J. (Ed.), The Amazing Power of Cooperatives, Quebec 2012 International Summit of Co-operatives, pp.289-299.

Parker, M., Cheney, V., Fournier, V. \& Land, C. (Eds.) (2014). The Routledge Companion to Alternative Organization. London: Routledge.

Puusa, A., Monkkonen, K. \& Varis, A. (2013). Mission lost? dilemmatic dual nature of co-operatives, Journal of Cooperative Organization and Management, 1(1): 6-14. DOI: https://doi.org/10.1016/j.jcom.2013.06.002

Ryan, G. \& Bernard, R. (2003). Techniques to identify themes, Field Methods, 15: 84-109. DOI: https://doi. org/10.1177/1525822x02239569

Sandoval, M. (2016). Fighting precarity with co-operation? Worker co-operatives in the cultural sector, New Formations, 88(88): 51-68. DOI: https://doi.org/10.3898/NEWF.88.04.2016

Snyder, M. \& Briggs, X. (2003). Communities of practice: a new tool for government managers. IBM Centre for the Business of Government. http://www.social-capital.net/docs/CoPs_and_gvt_.pdf [Accessed: 28 June 2012].

Somerville, P. (2007). Co-operative identity, Journal of Co-operative Studies, 40(1): 5-17. 
Storey, J., Basterretxea, I. \& Salaman, G. (2014). Managing and resisting 'degeneration' in employee-owned businesses: a comparative study of two large retailers in Spain and the UK, Organization, 21(5): 626-644. DOI: https://doi. org/10.1177/1350508414537624

Takacs, D. (2003). How does your positionality bias your epistemology? The NEA Higher Education Journal, Summer, pp.27-38.

Varman, R. \& Chakraberti, M. (2004). Contradictions of democracy in a workers' cooperative, Organization Studies, 25(2): 183-208. DOI: https://doi.org/10.1177/0170840604036913

Vieta, M. (2012). From managed employees to self-managed workers: The transformations of labour at Argentina's worker-recuperated enterprises. In: Atzeni, M. (Ed.), Alternative Work Organizations. Palgrave Macmillan UK, pp.129-156.

Webb, T. \& Cheney, G. (2014). Worker-owner-and-governed co-operatives and the wider co-operative movement: Challenges and opportunities within and beyond the global economic crisis. In: M. Parker, V. Cheney, V. Fournier \& C. Land (Eds.), The Routledge Companion to Alternative Organization. London: Routledge.

Wenger, E. (1998). Communities of practice: learning, meaning and identity. New York: Cambridge University Press.

Wenger, E. (2000). Communities of practice and social learning systems, Organization, 7(2): 225-246. DOI: https://doi. org/10.1177/135050840072002

Wenger, E., McDermott, R. \& Snyder, W. (2002). Cultivating communities of practice. Massachusetts: Harvard Business School Press. 